\title{
miR-29b enhances prostate cancer cell invasion independently of MMP-2 expression
}

\author{
Renato F. Ivanovic ${ }^{1 *}$ (D), Nayara I. Viana ${ }^{1}$, Denis R. Morais ${ }^{1}$, Iran A. Silva' ${ }^{1}$ Katia R. Leite ${ }^{1}$, José Pontes-Junior ${ }^{1}$, \\ Gustavo Inoue ${ }^{1}$, William C. Nahas ${ }^{2}$, Miguel Srougi ${ }^{1}$ and Sabrina T. Reis ${ }^{1}$
}

\begin{abstract}
Background: The ability to metastasize is one of the most important characteristics of neoplastic cells. An imbalance between the action of some matrix metalloproteinases (MMPs) and tissue inhibitors of MMPs drives the invasion process. Some studies have suggested that MMP-2 is involved in metastasis, while other studies have reported that collagen production by cancer cells might also contribute to motility. However, decreased expression of microRNA-29b (miR-29b), which may control MMP-2 and collagen gene expression, has been shown in prostate cancer (PCa). The objectives of the present study were to clarify whether MMP-2 as well as collagens I and III (encoded by COL1A1 and COL3A1, respectively) are controlled by miR-29b and to determine whether metastasis is altered by this relationship.

Methods: PCa DU145 and PC-3 cells were transfected with $100 \mu \mathrm{L}$ of OPTI-MEM I containing $100 \mathrm{nmol}$ of miR-29b (or its inhibitor) along with $1.5 \mu \mathrm{L}$ of lipofectamine. Positive and negative controls were prepared using the same protocol. MMP-2, COL1A1 and COL3A1 messenger RNA (mRNA) levels were evaluated via real-time polymerase chain reaction (qRT-PCR). For qRT-PCR, $6 \times 10^{4}$ cells were used. Invasion studies were conducted with Matrigel assays, which simulate invasion of the extracellular matrix by neoplastic cells. After transfection of $3 \times 10^{4}$ cells, invasion was allowed to proceed for $48 \mathrm{~h}$. Invasive cells were counted under an optical microscope. Each experiment was performed in triplicate.
\end{abstract}

Results: MMP-2 mRNA was not expressed in DU145 cells after transfection with miR-29b. After transfection of cells with the miR-29b inhibitor, COL1A1 $(p=0.02)$ and COL3A1 $(p=0.06)$ mRNA expression was increased in DU145 cells, and a large number of transfected DU145 and PC3 cells invaded the Matrigel membrane.

Conclusions: In vitro studies showed that reducing the amount of miR-29b may lead to higher PCa cell invasion via a process that is independent of MMP-2. Collagen expression, controlled by miR-29b, may facilitate this motility process. Thus, the present study suggests that collagen production plays an active role in metastasis control and restoration of miR-29b levels may decrease metastasis. Altogether, these findings support further exploration of drug therapy targeting this aspect of the metastasis circuit.

Keywords: Prostate cancer, Matrix metalloproteinases, Collagen, microRNA

\section{Background}

Extracellular matrix (ECM) disruption by matrix metalloproteinases (MMPs) is one of the key events in metastasis. MMPs are regulated not only by their natural inhibitors, tissue inhibitors of MMPs (TIMPs), but also at

\footnotetext{
*Correspondence: rfidelisivanovic@gmail.com

1 Laboratory of Medical Investigation (LIM55), Urology Department,

University of Sao Paulo Medical School, Av. Dr. Arnaldo 455, $2^{\circ}$ floor, room

2145, Sao Paulo 01246-903, Brazil

Full list of author information is available at the end of the article
}

the post-transcriptional level by microRNAs (miRNAs). One of these MMPs is MMP-2, which may be involved in prostate cancer $(\mathrm{PCa})$ progression and metastasis $[1,2]$.

However, there is evidence that interstitial collagen may be involved in metastasis, indicating an active role for the desmoplastic reaction observed in several cancers. Increased production of several types of collagens has been reported: type II and IV collagens were observed in osteosarcoma [3], collagen type $\mathrm{V}$ was produced at elevated levels by fibrosarcoma cells compared 
with its production in normal muscle cells [4], and increased production of collagens I and III was observed in ovarian carcinoma [5]. Additionally, researchers have reported that collagen expression can facilitate neoplastic cell spreading [6].

The COL1A1 and COL3A1 genes encode the alpha-1 chains of collagen types 1 and 3, respectively, which are present in most connective tissues. Type 1 collagen is present in almost $70 \%$ of the extracellular bone matrix. Previously, Steele et al. [7] reported that a single miRNA (miR-29b) regulates MMP-2, COL1A1 and COL3A1 genes, although an assay to evaluate metastasis was not employed. Subsequently, Ru et al. showed that miR-29b overexpression in $\mathrm{PCa}$ cell lines limits metastasis, but this study did not focus on collagen genes or MMP-2 and finally Yan et al. [8] employed only LnCaP cells to report that miR-29b upregulation inhibits metastasis and that MMP-2 was not involved in this issue. Therefore, the debate about the relationship between MMP-2, miR-29b, collagen genes and metastases still persists in PCa. Thus, the aim of the present study was to evaluate in vitro whether transfection of PCa cell lines with miR$29 \mathrm{~b}$ affects metastasis through modification of collagen and MMP-2 gene expression.

\section{Method}

\section{MicroRNAs}

mir-29b, anti-miR-29b and positive and negative controls (Ambion, Austin, TX, USA) were diluted in a $10 \mu \mathrm{M}$ stock solution and frozen at $-20{ }^{\circ} \mathrm{C}$ until further use. All experiments were performed in triplicate.

\section{Cell lines}

The following cell lines were used: DU145 and PC3 (American Type Culture Collection-ATCC). The cells were cultured in DMEM or MEM supplemented with $10 \%$ fetal bovine serum (FBS) and $1 \%$ antibiotic/antimycotic solution (Sigma Co., St. Louis, MO, USA). Cell cultures were incubated at $37{ }^{\circ} \mathrm{C}$ in $95 \%$ air and $5 \% \mathrm{CO}_{2}$.

\section{Cell transfection}

Lipofectamine-based transfection (siPORT NeoFX, Ambion, USA) was performed with $2.5 \mu \mathrm{L}$ of a $10 \mu \mathrm{M}$ miRNA stock solution of miR-29b or miR-29b inhibitor. Each inhibitor solution was diluted in $50 \mu \mathrm{L}$ of OPTIMEM and mixed with $1.5 \mu \mathrm{L}$ of Lipofectamine also diluted in $50 \mathrm{~mL}$ of OPTI-MEM I. The transfection complex $(100 \mu \mathrm{L})$ was placed in a 12 -well culture plate and incubated for $24 \mathrm{~h}$ in $\mathrm{CO}_{2}$ at $37^{\circ} \mathrm{C}$. Positive and negative controls were employed in the study. All experiments were performed in triplicate.

\section{Total RNA and miRNA extraction}

At $24 \mathrm{~h}$ after transfection, the cells were trypsinized, washed with $10 \%$ RPMI and centrifuged at $4000 \mathrm{rpm}$ for $5 \mathrm{~min}$. Total RNA and miRNA were extracted using a mirVana kit according to the manufacturer's instructions (Applied Biosystems). The purity and concentration of the miRNA and RNA were measured with a spectrophotometer (ND-1000, Thermo Scientific, Wilmington, USA) at wavelengths of 260 and $280 \mathrm{~nm}$ (A260/280).

\section{Reverse transcription (RT)}

Reverse transcription was performed using a TaqMan Reverse Transcription kit (Applied Biosystems, Foster City, CA, USA) according to the manufacturer's instructions. MMP-2 cDNA was synthesized with $5 \mathrm{ng}$ of mRNA (High-Capacity cDNA Reverse Transcription Kit, Applied Biosystems) using reverse transcriptase and random primers.

For miRNA, the reaction was performed with Veriti equipment (Applied Biosystems, Foster City, CA) according to the following parameters: $30 \mathrm{~min}$ at $16{ }^{\circ} \mathrm{C}, 30 \mathrm{~min}$ at $42{ }^{\circ} \mathrm{C}$ and 5 min at $85{ }^{\circ} \mathrm{C}$. The cDNA from RNA was obtained with same equipment using the following parameters: $10 \mathrm{~min}$ at $25^{\circ} \mathrm{C}, 120 \mathrm{~min}$ at $37^{\circ} \mathrm{C}$ and $5 \mathrm{~min}$ at $85^{\circ} \mathrm{C}$.

\section{Real-time PCR}

We used an ABI 7500 FAST thermocycler system to assess transfection efficacy and the expression of COL1A1/ COL3A1 and MMP-2 genes under the following conditions: $0.5 \mu \mathrm{L}$ of specific primer, $5 \mu \mathrm{L}$ of TaqMan ${ }^{\circledR}$ Universal PCR Master Mix (Applied Biosystems, California, USA), $3.5 \mu \mathrm{L}$ of nuclease-free water and $1 \mu \mathrm{L}$ of cDNA. The PCR cycles were as follows: $2 \mathrm{~min}$ at $50^{\circ} \mathrm{C}, 10 \mathrm{~min}$ at $95^{\circ} \mathrm{C}$, and 40 cycles of $15 \mathrm{~s}$ at $95^{\circ} \mathrm{C}$ and $1 \mathrm{~min}$ at $60^{\circ} \mathrm{C}$. The endogenous control was B2M for genes and RNU43 for miRNAs. The miRNA and target gene expression levels were obtained, and the relative quantification of the expression levels was determined using the $2^{-\Delta \Delta \mathrm{ct}}$ method [9].

\section{Invasion assays}

Using PC3 and DU145 cell lines, invasion was measured by counting the number of cells that invaded into the lower portion of Transwell chambers (Becton-Dickinson) with a pore size of $8 \mu \mathrm{m}$ containing $50 \mathrm{~mL}$ of Matrigel diluted in serum-free culture medium (1:2). A total of $3 \times 10^{4}$ cells $/ \mathrm{mL}$ in serum-free culture medium were seeded onto the Matrigel, and $750 \mu \mathrm{L}$ of culture medium containing FBS (10\%) was added to the lower chamber. The cells were maintained in a $\mathrm{CO}_{2}$ incubator for $24-32 \mathrm{~h}$ at $37^{\circ} \mathrm{C}$. The cells were fixed with formaldehyde in PBS (4\%), stained with crystal violet solution (1\%) 
in methanol and counted using an optical microscope at $20 \times$ magnification.

\section{Results}

\section{MMP-2 gene expression}

DU145 cells were transfected with miR-29b or its inhibitor. However, there was no MMP-2 amplification. We decided to extract total RNA from DU145 and PC3 cultured cell lines (without any transfection) and from a $\mathrm{PCa}$ tissue sample. The MMP-2 mRNA was amplified in the tissue samples but in neither of the cell lines.

\section{COL1A1 and COL3A1 mRNA expression}

In DU145 cell lines, miR-29b inhibition significantly increased COL1A1 $(248 \%, \mathrm{p}=0.02, \mathrm{SD}=1.84)$ and COL3A1 mRNA levels $(86 \%, \mathrm{p}=0.06, \mathrm{SD}=0.59)$. However, miR-29 overexpression did not change the expression of those mRNAs (Fig. 1).

\section{Matrigel assay}

miR-29b inhibition increased the number of cells invading through the Matrigel membrane in both the DU145 $(\mathrm{p}=0.04)$ and PC3 cell lines $(\mathrm{p}=0.016)$ (Figs. 2,3$)$.
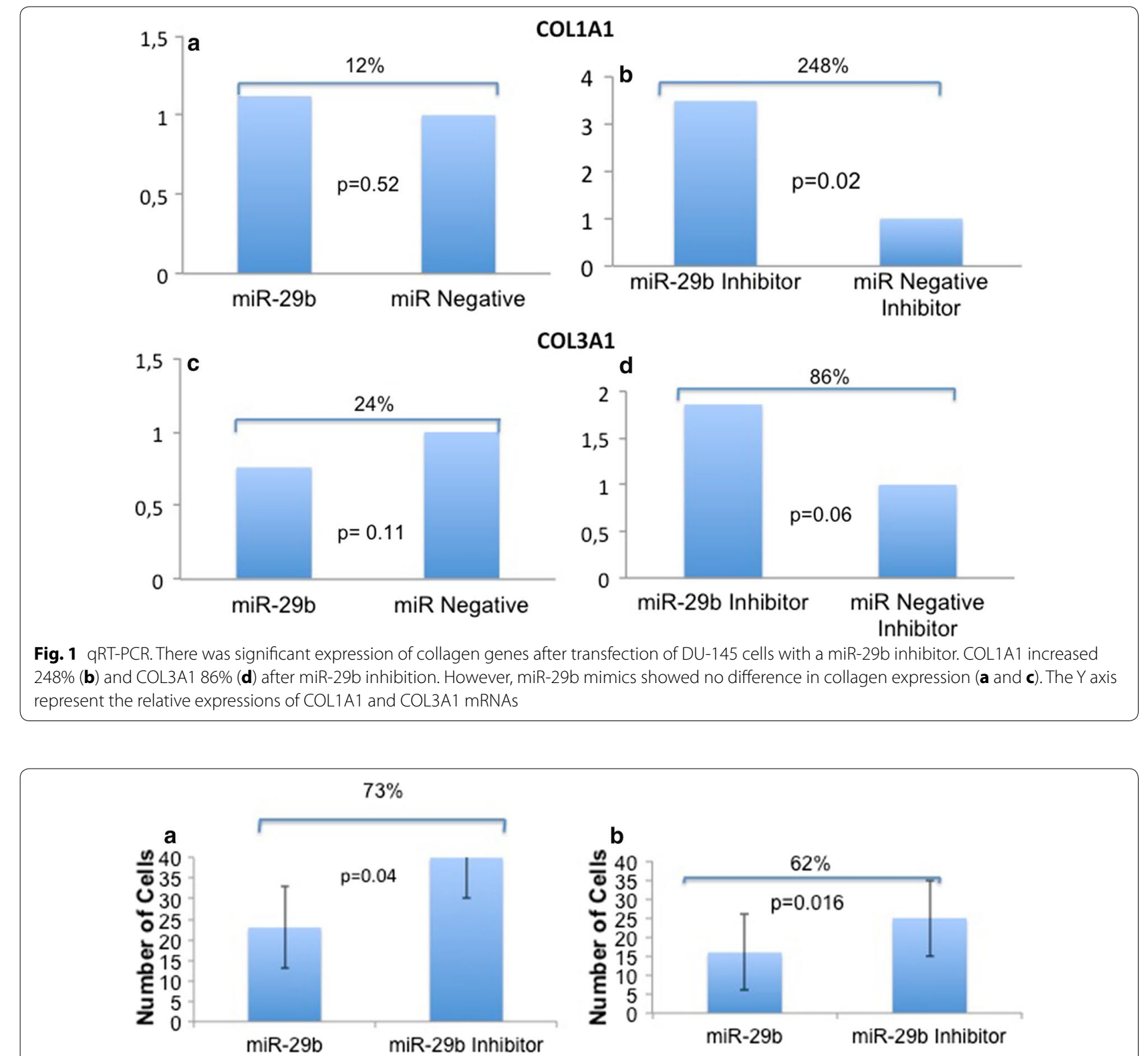

Fig. 2 Matrigel experiment. The number of cells that crossed the Matrigel membrane was significantly higher in DU145 (a) and PC3 (b) cell lines after transfection with the miR-29b inhibitor 


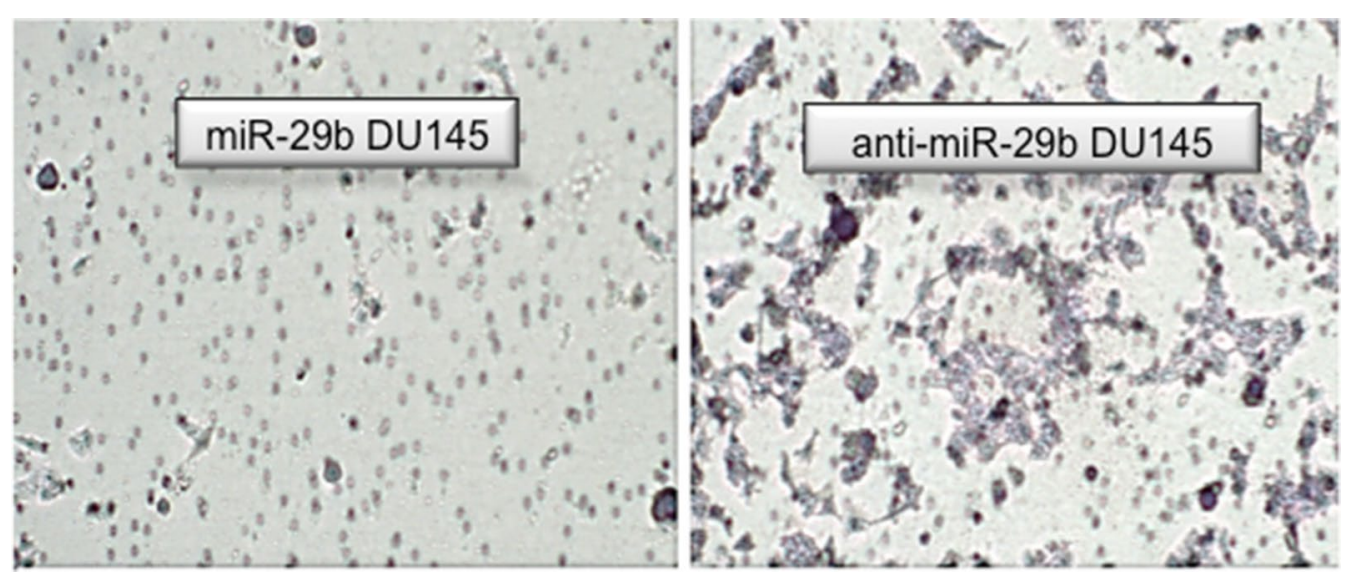

Fig. 3 Matrigel chamber photography. Visual representation of the increased invasion of DU145 cells after miR-29b inhibition

\section{Discussion}

Desmoplasia refers to interstitial collagen production in cancer. Collagen types I and III are two of the most important molecules that support tissue structure in solid organs. Decades ago, Waisman et al. [10] observed that the production of extracellular material was an important feature of granulosa-theca tumors, and the culture of chondrosarcoma cells provided evidence of increased collagen production compared to that in normal cells [11].

Richards et al. [12] studied the growth of normal and neoplastic mouse mammary cells on three different substrates: plastic, rat tail, and rat tail collagen. Increased cell growth was reported when collagen was used as a substrate, primarily because the cells produced a structure that resembled collagen IV and laminin. Further, these authors provided evidence that the cells could actively produce collagen, because CIS-OH-proline (which blocks collagen production) inhibited cell growth.

As epithelial cells change their environment, they acquire functions of stromal cells, and collagen production may be one consequence of this transformation [13]. Another example of the interaction between malignant cells and the extracellular environment was provided by Noel et al., who showed higher collagen production in cocultures of MCF7 malignant cells and fibroblasts on a substrate containing type I collagen [14]. However, these authors hypothesized that the collagen was produced not by malignant cells but by fibroblasts. One of the hypotheses regarding the collagen production in neoplastic diseases was that this event functions as an attempt to construct a barrier that can halt tumor spread. However, Hewitt et al. [15] reported that intense collagen production occurred at the center of colon malignancies, in contrast with that observed at the edge where the invasion occurred. These authors, as well as a study published by other authors [14], also considered collagen production by stromal cells. In pancreatic cancer, the desmoplastic reaction occurs with increased production of collagen types I and III, which are primarily stimulated by TGF- $\beta$ from granulocytes, suggesting an interaction between malignant epithelial cells and the stroma [16]. In renal neoplasms, the myofibroblasts identified in the tumor capsule have high type I collagen mRNA expression, likely also induced by TGF- $\beta$ [17].

Kaupilla et al. [5] investigated whether fibroblasts or epithelial cells were responsible for the production of collagen types I and III in ovarian cystadenomas and cystadenocarcinomas. These authors demonstrated through in situ hybridization that poorly differentiated tumors could produce type I and III collagens. These authors also highlighted that collagen mRNA does not always translate into fibrils, except in ovarian cancer.

In $\mathrm{PCa}$, there is evidence of collagenous micronodule deposition in biopsy and prostatectomy samples [18]. Further, intense desmoplastic activity was observed in intermediate and high-grade $\mathrm{PCa}$, which also showed increased expression of vimentin, IGF-1, MMP-2, FGF2, c-Myc, PSCA and Era [19], and an intense reactive stroma has been reported to distinguish benign from malignant prostatic tissue [20]. Such findings highlight the importance of extracellular collagen as a microenvironment component that can enhance metastasis. In other words, changes in the ECM created by tissue fibrosis can enhance tumor progression [21].

Previous studies have shown that malignant cells have reduced levels of miR-29b [22], and other studies have demonstrated reduced miR-29b expression in prostate cell lines and human prostate adenocarcinoma tissues $[23,24]$. 
miR-29b inhibition leads to increased expression of the collagen I, III and V genes in PCa, as reported by Steele et al. [7], and the present results are consistent with these findings. However, in the present study, we found that miR-29b inhibition leads to increased collagen gene expression and further augments metastasis. We would expect that the increased cell invasion in the Matrigel assay was due to MMP-2 overexpression promoted by miR-29b inhibition, because this miRNA was previously shown to control MMP-2. However, because we did not observe MMP-2 mRNA expression in the examined cell lines, it is possible that invasion occurred with collagen gene expression independently of MMP-2. One possible explanation was provided by the results of other studies showing that MMP-2 is primarily expressed by stromal cells, as evidenced by the low to absent MMP-2 levels found in conditioned medium of PCa epithelial cells determined by zymography, whereas stromal cells exhibited higher levels of this protein [25]. Another study conducted by Yan et al. reported decreased cell invasion after miR-29b overexpression only with LncaP cells and without modification of MMP-2 levels. Then, our results obtained with another cell line (DU145) are in line with them [8].

A limitation of the present study is that these results could be improved with ELISA or western blotting to confirm at the protein level the increased collagen production induced by miR-29b downregulation in $\mathrm{PCa}$ cells. Another question raised in the present study is whether COL1A1/COL3A1 forms fibrils or if these collagens act as molecules that activate the metastasis pathway. Independently, the observed behavior of PCa cells after miR-29b inhibition indicated increased metastatic potential.

Thus, the present study showed that miR-29b inhibition increases cell invasion, and the expression of COL1A1 and COL3A1 genes in PC3 and DU145 prostate cell lines is independent of MMP-2. Thus, collagen expression may play an active role in metastasis physiology.

\section{Conclusions}

Blockade of miR-29b leads to increased mRNA expression of type I (COL1A1) and type III (COL3A1) collagens and enhances the invasion of PC3 and DU145 cells lines in vitro. This finding provides a possible role for the desmoplastic reaction. This mechanism was independent of the expression of MMP-2, and therapies that restore miR-29b levels might be promising alternatives for controlling the metastatic pathway in PCa.

\section{Abbreviations}

MMP: matrix metalloproteinase; TIMP: tissue inhibitor of matrix metalloproteinase; PCa: prostate cancer; mRNA: messenger RNA; qRT-PCR: quantitative real-time polymerase chain reaction; ECM: extracellular matrix; miRNA: microRNA; miR-29b: microRNA 29b.

\section{Authors' contributions}

RFI performed most of the experiments; NIA assisted with the cell culture; DRM assisted with the data interpretation; IAS assisted with the Matrigel experiments; KRL and JPJ revised the manuscript; GI contributed to the manuscript by performing the Matrigel experiments during his scientific initiation program; WCN and MS provided support with the laboratory equipment; and STR coordinated and guided the steps of the work. All authors read and approved the final manuscript.

\section{Author details \\ ${ }^{1}$ Laboratory of Medical Investigation (LIM55), Urology Department, University of Sao Paulo Medical School, Av. Dr. Arnaldo 455, $2^{\circ}$ floor, room 2145, Sao Paulo 01246-903, Brazil. ${ }^{2}$ Uro-Oncology Group, Urology Department, Univer- sity of Sao Paulo Medical School and Institute of Cancer Estate of Sao Paulo (ICESP), Sao Paulo, Brazil.}

\section{Acknowledgements}

Not applicable.

\section{Competing interests}

The authors declare that they have no competing interests.

\section{Availability of data and materials}

The datasets used and/or analyzed in the present study are available from the corresponding author upon reasonable request.

\section{Consent for publication}

Not applicable.

Ethics approval and consent to participate

Not applicable.

\section{Funding}

Funding was received from the State of Sao Paulo (FAPESP): 2012/21833-8; 2015/00845-6.

\section{Publisher's Note}

Springer Nature remains neutral with regard to jurisdictional claims in published maps and institutional affiliations.

Received: 3 December 2017 Accepted: 31 January 2018

Published online: 05 February 2018

References

1. Stearns ME, Stearns M. Immunohistochemical studies of activated matrix metalloproteinase-2 (MMP-2a)expression in human prostate cancer. Oncol Res. 1996;8(2):63-7.

2. Kanoh Y, Akahoshi T, Ohara T, Ohtani N, Mashiko T, Ohtani S, Egawa S, Baba S. Expression of matrix metalloproteinase-2 and prostate-specific antigen in localized and metastatic prostate cancer. Anticancer Res. 2002;22(3):1813-7.

3. Lanzer WL, Liotta LA, Yee C, Azar HA, Costa J. Synthesis of pro-collagen type II by a xenotransplanted human chondroblastic osteosarcoma. Am J Pathol. 1981;104(3):217-26.

4. Asokan R, Reddy GK, Dhar SC. Neoplastic association of enhanced type $\mathrm{V}$ collagen production in rat fibrosarcoma. Mol Cell Biochem. 1993;120(1):25-32.

5. Kauppila S, Saarela J, Stenback F, Risteli J, Kauppila A, Risteli L. Expression of mRNAs for type I and type III procollagens in serous ovarian cystadenomas and cystadenocarcinomas. Am J Pathol. 1996;148(2):539-48.

6. Cox TR, Bird D, Baker AM, Barker HE, Ho MW, Lang G, Erler JT. LOX-mediated collagen crosslinking is responsible for fibrosis-enhanced metastasis. Cancer Res. 2013;73(6):1721-32. 
7. Steele R, Mott JL, Ray RB. MBP-1 upregulates miR-29b that represses Mcl-1, collagens, and matrix-metalloproteinase-2 in prostate cancer cells. Genes Cancer. 2010;1 (4):381-7.

8. Yan B, Guo Q, Nan XX, Wang Z, Yin Z, Yi L, Wei YB, Gao YL, Zhou KQ, Yang JR. Micro-ribonucleic acid 29b inhibits cell proliferation and invasion and enhances cell apoptosis and chemotherapy effects of cisplatin via targeting of DNMT3b and AKT3 in prostate cancer. Onco Targets Ther. 2015;8:557-65.

9. Livak KJ, Schmittgen TD. Analysis of relative gene expression data using real-time quantitative PCR and the 2(-Delta Delta C(T)) method. Methods. 2001:25(4):402-8.

10. Waisman J, Lischke JH, Mwasi LM, Dignam WJ. The ultrastructure of a feminizing granulosa-theca tumor. Am J Obstet Gynecol. 1975;123(2):147-50.

11. Miller DR, Treadwell BV, Mankin HJ. De novo protein synthesis by human chondrosarcoma in cell and organ culture: evidence of unusually high collagen production by a neoplastic tissue. Connect Tissue Res. 1980;8(1):9-20.

12. Richards J, Pasco D, Yang J, Guzman R, Nandi S. Comparison of the growth of normal and neoplastic mouse mammary cells on plastic, on collagen gels and in collagen gels. Exp Cell Res. 1983;146(1):1-14.

13. Adams AT, Auersperg N. A cell line, ROSE 199, derived from normal rat ovarian surface epithelium. Exp Cell Biol. 1985;53(4):181-8.

14. Noel A, Munaut C, Nusgens B, Foidart JM, Lapiere CM. The stimulation of fibroblasts' collagen synthesis by neoplastic cells is modulated by the extracellular matrix. Matrix. 1992;12(3):213-20.

15. Hewitt RE, Powe DG, Carter GI, Turner DR. Desmoplasia and its relevance to colorectal tumour invasion. Int J Cancer. 1993;53(1):62-9.

16. Aoyagi Y, Oda T, Kinoshita T, Nakahashi C, Hasebe T, Ohkohchi N, Ochiai A. Overexpression of TGF-beta by infiltrated granulocytes correlates with the expression of collagen mRNA in pancreatic cancer. Br J Cancer. 2004;91(7):1316-26.
17. Shimasaki N, Kuroda N, Guo L, Jin Y, Miyazaki E, Hayashi Y, Toi M, Hiroi M, Enzan $\mathrm{H}$, Shuin T. The participation of myofibroblasts in the capsular formation of human conventional and chromophobe renal cell carcinomas. Histol Histopathol. 2005;20(1):67-73.

18. Bostwick DG, Wollan P, Adlakha K. Collagenous micronodules in prostate cancer. A specific but infrequent diagnostic finding. Arch Pathol Lab Med. 1995:119(5):444-7.

19. Silva MM, Matheus WE, Garcia PV, Stopiglia RM, Billis A, Ferreira U, Fávaro WJ. Characterization of reactive stroma in prostate cancer: involvement of growth factors, metalloproteinase matrix, sexual hormones receptors and prostatic stem cells. Int Braz J Urol. 2015;41(5):849-58.

20. Tomas D, Kruslin B. The potential value of (Myo)fibroblastic stromal reaction in the diagnosis of prostatic adenocarcinoma. Prostate. 2004;61(4):324-31.

21. CoxTR, Erler JT. Remodeling and homeostasis of the extracellular matrix: implications for fibrotic diseases and cancer. Dis Model Mech. 2011;4(2):165-78.

22. Schmitt MJ, Margue C, Behrmann I, Kreis S. MiRNA-29: a microRNA family with tumor-suppressing and immune-modulating properties. Curr Mol Med. 2013;13(4):572-85.

23. Ru P, Steele R, Newhall P, Phillips NJ, Toth K, Ray RB. miRNA-29b suppresses prostate cancer metastasis by regulating epithelial-mesenchymal transition signaling. Mol Cancer Ther. 2012;11(5):1166-73.

24. Katz B, Reis ST, Viana NI, Morais DR, Moura CM, Dip N, Silva IA, Iscaife A, Srougi M, Leite KR. Comprehensive study of gene and microRNA expression related to epithelial-mesenchymal transition in prostate cancer. PLoS ONE. 2014;9(11):e113700.

25. Wilson MJ, Sellers RG, Wiehr C, Melamud O, Pei D, Peehl DM. Expression of matrix metalloproteinase-2 and -9 and their inhibitors, tissue inhibitor of metalloproteinase- 1 and -2 , in primary cultures of human prostatic stromal and epithelial cells. J Cell Physiol. 2002;191(2):208-16.

\section{Submit your next manuscript to BioMed Central and we will help you at every step:}

- We accept pre-submission inquiries

- Our selector tool helps you to find the most relevant journal

- We provide round the clock customer support

- Convenient online submission

- Thorough peer review

- Inclusion in PubMed and all major indexing services

- Maximum visibility for your research

Submit your manuscript at www.biomedcentral.com/submit
O Biomed Central 